\title{
Optimization of Coagulation-flocculation Process for Pre-treatment of Artisanal Tannery Wastewater Using Response Surface Methodology
}

Miriam Appiah-Brempong ( $\nabla$ esisamiriam@yahoo.co.uk)

Kwame Nkrumah University of Science and Technology https://orcid.org/0000-0002-4063-5065

Helen Michelle Korkor Essandoh

Kwame Nkrumah University of Science and Technology

Nana Yaw Asiedu

Kwame Nkrumah University of Science and Technology

Samuel Kwame Dadzie

Kwame Nkrumah University of Science and Technology

Francis Yao Momade

Kwame Nkrumah University of Science and Technology

\section{Research Article}

Keywords: Aluminium sulphate, Central composite design, Colour, Chemical oxygen demand, Removal efficiency, Sludge volume index

Posted Date: September 29th, 2021

DOI: https://doi.org/10.21203/rs.3.rs-838770/v1

License: (c) (1) This work is licensed under a Creative Commons Attribution 4.0 International License. Read Full License 
3 Miriam Appiah-Brempong ${ }^{1 *}$, Helen Michelle Korkor Essandoh ${ }^{2}$, Nana Yaw Asiedu ${ }^{3}$, Samuel

$4 \quad$ Kwame Dadzie ${ }^{4}$, Francis Yao Momade ${ }^{5}$

$5{ }^{1}$ College of Engineering, Kwame Nkrumah University of Science and Technology, Kumasi,

6 Ghana; esisamiriam@yahoo.co.uk

$7{ }^{2}$ Regional Water and Environmental Sanitation Centre, Kumasi, Department of Civil Engineering, 8 College of Engineering, Kwame Nkrumah University of Science and Technology, Kumasi, Ghana;

9 hmanipa@yahoo.com

$10{ }^{3}$ Department of Chemical Engineering, College of Engineering, Kwame Nkrumah University of 11 Science and Technology, Kumasi, Ghana; nasiedusoe@yahoo.co.uk

$12{ }^{4}$ Regional Water and Environmental Sanitation Centre, Kumasi, Department of Civil Engineering, 13 College of Engineering, Kwame Nkrumah University of Science and Technology, Kumasi, Ghana; 14 sdadzie855@gmail.com

$15{ }^{5}$ Department of Materials Engineering, College of Engineering, Kwame Nkrumah University of 16 Science and Technology, Kumasi, Ghana; fmomade@yahoo.com

17 *Correspondence: esisamiriam@yahoo.co.uk

\section{Abstract}

19 There is a dearth in knowledge on artisanal tannery wastewater treatment as most studies are

20 focused on treatment of wastewater generated from modern-day leather manufacturing industries.

21 The extensive use of plant materials in artisanal tanneries introduces high loads of polyphenolic 
22 compounds in the wastewater rendering biological treatment of the wastewater ineffective. This

23 study, therefore, employed coagulation-flocculation process to pre-treat artisanal tannery

24 wastewater with the aim of applying the central composite design, a statistical approach in

25 Response Surface Methodology (RSM) to model and optimize the removal of Chemical Oxygen

26 Demand (COD), Total Suspended Solids (TSS) and turbidity and to minimize Sludge Volume

27 Index (SVI). Optimization process focused on the two most important influencing parameters:

28 dosage of aluminium sulphate and initial $\mathrm{pH}$ of wastewater. Results revealed that optimal $\mathrm{pH}$ and

29 aluminium sulphate dosage of 6.09 and $11.6 \mathrm{~g} / \mathrm{L}$ respectively could yield maximum removal

30 efficiencies of $38.51 \%$ of COD, $76.05 \%$ of TSS and $79.64 \%$ of turbidity from the wastewater with

31 a minimum SVI of $29.57 \mathrm{~mL} / \mathrm{g}$. Further experiments conducted to validate these results showed a

32 good agreement between the experimental and predicted results signifying the suitability of RSM

33 for optimization of the coagulation treatment process. This is the first reported study on

34 optimization of coagulation-flocculation treatment of artisanal tannery wastewater. Results of this

35 study can be used practically for efficient pre-treatment of artisanal tannery wastewater.

36 Keywords Aluminium sulphate, Central composite design, Colour, Chemical oxygen demand,

37 Removal efficiency, Sludge volume index

\section{$38 \quad$ Introduction}

39 Wastewater originating from tanneries are toxic, malodourous, strongly coloured and heavily laden

40 with dissolved and suspended matter, organic and inorganic contaminants (Zhao \& Chen 2019).

41 Discharge of the untreated wastewater is therefore, extremely harmful to both human and

42 environmental health. As a result, numerous researches investigating into different treatment

43 options for tannery wastewater have been conducted over the years. Different methods of treatment

44 including coagulation, adsorption, reverse osmosis, electrocoagulation, ion exchange and 
45 ultrafiltration have been proposed (Durmaz \& Çiner 2017). However, a large number of these

46 researches have been centered primarily on wastewater generated from modern-day tanneries with

47 very little attention given to that originating from artisanal tanneries. Meanwhile, modern-day

48 leather making (Thanikaivelan et al. 2005; Covington 1997) differs significantly from that of

49 artisanal leather making (Appiah-Brempong et al. 2020; Wemegah 2014) in its manufacturing

50 processes, type of process chemicals and equipment used and even the characteristics of the

51 wastewater generated.

52 Although, it is estimated that $90 \%$ of tanneries world-wide engage in modern-day leather

53 production practices (Dargo \& Ayalew 2014), artisanal leather making is still an important source

54 of livelihood for many people in most developing countries including Ghana (Wemegah 2014),

55 Cameroon (Paltahe et al. 2019), Ethiopia (Gebremichael 2016), Nigeria (Zaruwa \& Kwaghe 2014)

56 and Sudan (Skinner 2007). Wastewater emanating from these artisanal tanneries is usually

57 discarded into the environment without treatment. In Ghana, for instance, the untreated wastewater

58 is discarded on the tannery grounds which is a potential source of pollution to soil, surface water,

59 groundwater bodies and the surrounding atmosphere (Islam et al. 2014).

60 The predominant use of vegetative materials in the leather manufacturing process in artisanal

61 tanneries generates wastewater composed of large quantities of polyphenolic compounds which

62 are recalcitrant and toxic to microorganisms making biological treatment of the wastewater an

63 inefficient option (Schrank et al. 2004). Coagulation-flocculation process, a physicochemical

64 treatment method which is robust against wastewater toxicity and highly efficient in removal of

65 both organic and suspended contaminants from wastewater (Aboulhassan et al. 2006) was,

66 therefore, employed in this study. It is a commonly used wastewater pretreatment technology due

67 to its efficiency and simplicity in its design and operation (Shewa \& Dagnew 2020). The 
mechanism involved in the coagulation-flocculation treatment process is by the initial

69 destabilization of colloidal particles in the wastewater during the coagulation phase and the

70 subsequent aggregation of the destabilized colloids into floc particles during the flocculation

71 phase. The floc particles are then separated through sedimentation processes as they settle under

72 gravity (Maćczak et al. 2020).

73 Aluminium sulphate is one of the most widely used coagulants due to its availability, relatively

74 low cost and high coagulation performance (Shewa \& Dagnew 2020). Nevertheless, it suffers a 75 major drawback of releasing toxic aluminium ions into the environment, particularly when applied 76 in excess. Long-term exposure to aluminium can result in bioaccumulation of the ions in humans, 77 nervous breakdown and Alzheimer's diseases. Aluminium ions in the soil can also hamper plant 78 growth and restrict nutrient uptake (Jaishankar et al. 2014). Thus, it is imperative to optimize the 79 amount of aluminium sulphate used in wastewater treatment to protect human and environmental 80 health.

81 Various factors influence the coagulation-flocculation process. These include temperature, $\mathrm{pH}$, 82 coagulant type and dosage as well as mixing speed (Wang et al. 2014). Among these factors, pH 83 and coagulant dosage have been identified as the most important parameters influencing the 84 coagulation-flocculation process (Verma et al. 2012). Optimization of these factors enhances 85 coagulation efficiency and maximizes removal efficiency of contaminants from the wastewater. 86 Conventionally, optimization of the coagulation process has been performed by varying one factor 87 at a time whilst maintaining all other variables constant. This method is not only laborious and 88 time-consuming but also expensive as it demands the performance of lots of experiments to define 89 the optimal conditions. Additionally, the actual optimal conditions may not be attained using the 90 conventional method since it ignores the effect of the interaction between the factors (Kumar et al. 
91 2018). The Response Surface Methodology (RSM), a statistical method makes use of design of

92 experiments to overcome these limitations of the conventional method. Through RSM, regression

93 models which describe the coagulation process can be developed, the statistical significance of the

94 various factors influencing the process can be determined, the interaction effect among the factors

95 can be assessed and the optimal process conditions can be defined (Bas \& Ismail 2007).

96 In light of this, this study aimed at using RSM to optimize the $\mathrm{pH}$ and the dosage of aluminium

97 sulphate required to maximize chemical oxygen demand, total suspended solids and turbidity

98 removal from artisanal tannery wastewater whilst minimizing the sludge volume index.

\section{$99 \quad$ Materials and Methods}

100 Wastewater sampling and characterisation

101 The wastewater was sampled from the Aboabo Tannery in Kumasi (Ashanti Region, Ghana)

102 located at $6^{\circ} 41^{\prime} 50.57^{\prime \prime} \mathrm{N} 1^{\circ} 36^{\prime} 7.02^{\prime \prime} \mathrm{W}$. The leather making process encompasses different activities

103 which include curing, soaking, liming, unhairing, deliming and bating, fleshing, vegetable tanning,

104 oiling, red, brown and black dyeing and drying. Detailed information on each of the production

105 stages have been reported by Appiah-Brempong et al. (2020). The wastewater generated is

106 primarily composed of the spent liquors arising from the vegetable tanning and red dyeing

107 processes as other liquors used in the production processes are rarely discarded. A composite

108 wastewater was formed by combining the spent liquors from the red dyeing and tanning processes

109 in a 1:3.33 ratio according to their generation rates.

110 Wastewater samples were collected on five occasions from the tannery during the study period.

111 The preservation and laboratory analyses of the samples were performed following the Standard

112 Methods for Examination of Water and Wastewater (APHA 1999). Parameters including pH, 
113 Electrical Conductivity (EC), Total Dissolved Solids (TDS) were tested using a portable 114 multipurpose meter. Turbidity and Total Suspended Solids (TSS) were also measured using 115 HANNA turbidimeter (HI 93414) and the gravimetric method respectively. The HACH methods

116 were employed in determining colour, Chemical Oxygen Demand (COD), ammonia ( $\left.\mathrm{NH}_{3}-\mathrm{N}\right)$ and

117 Total Nitrogen (TN) with the aid of the HACH DR 3900 spectrophotometer. The dilution method 118 in combination with dissolved oxygen measurement was used in determining the Biochemical 119 Oxygen Demand (BOD5). Chloride $\left(\mathrm{Cl}^{-}\right)$concentration was determined using the argentometric 120 method.

\section{Experimental procedure}

122 Laboratory grade aluminium sulphate hexadecahydrate $\left(\mathrm{Al}_{2}\left(\mathrm{SO}_{4}\right)_{3} .16 \mathrm{H}_{2} \mathrm{O}\right)$ reagent also termed as 123 alum (98\% purity; molar mass of $630.4 \mathrm{~g} / \mathrm{mol}$ ) obtained from QUALIKEMS Fine Chem Pvt. Ltd 124 was the coagulant used in the experiments. A $100 \mathrm{~g} / \mathrm{L}$ stock solution of aluminium sulphate was 125 prepared out of which appropriate volumes were measured and used in the experiments.

126 Coagulation experiments were performed at room temperature using the jar test apparatus (Stuart ${ }^{\circledR}$ 127 SW6 flocculator). Each 1L beaker was filled with 500mL of the tannery wastewater. The initial $128 \mathrm{pH}$ of the wastewater was altered using $0.1 \mathrm{MH}_{2} \mathrm{SO}_{4}$ and $100 \mathrm{~g} / \mathrm{L} \mathrm{Ca}(\mathrm{OH})_{2}$. Different volumes of 129 the stock solution of the aluminium sulphate were poured into the beakers. The different 130 adjustment in $\mathrm{pH}$ and coagulant dosage have been presented in Table 1 . The mixtures were initially 131 mixed rapidly at a speed of 250rpm for 1 minute and then slowly at 30rpm for 30 minutes (Kim 132 2016). After a settling time of 30 minutes, samples of the supernatant were taken from about $3 \mathrm{~cm}$ 133 below the surface for turbidity, COD, total suspended solids and $\mathrm{pH}$ tests. The volume of sludge 134 in each beaker was measured to compute the Sludge Volume Index (SVI) as shown in Equation 135 (1). The removal efficiency for turbidity, COD and TSS were computed according to Equation (2). 
136 All experiments were carried out in the Environmental Quality Engineering Laboratory of the

137 Kwame Nkrumah University of Science and Technology (Kumasi, Ghana).

$$
\begin{gathered}
\operatorname{SVI}(\mathrm{mL} / \mathrm{g})=\frac{\text { Volume of sludge }(\mathrm{mL} / \mathrm{L})}{\mathrm{TSS}(\mathrm{g} / \mathrm{L})} \\
\text { Removal Efficiency }(\%)=\frac{\mathrm{C}_{\mathrm{O}}-\mathrm{C}_{\mathrm{f}}}{\mathrm{C}_{\mathrm{O}}} \times 100 \%
\end{gathered}
$$

where, $C_{O}$ and $C_{f}$ are the initial and final concentrations of the measured COD (mg/L), TSS (mg/L) and turbidity (NTU) of the wastewater.

\section{Experimental design}

142 A statistical design tool in RSM, Central Composite Design (CCD) which is very efficient in

143 developing quadratic models was used in determining the influence of the two most important

144 independent variables $(n=2)$, coagulant dosage $\left(X_{1}\right)$ and initial wastewater $\mathrm{pH}\left(X_{2}\right)$ on four (4)

145 response variables $(Y)$ in the coagulation process. These responses are efficiencies of COD 146 removal $\left(Y_{1}\right)$, TSS removal $\left(Y_{2}\right)$, turbidity removal $\left(Y_{3}\right)$ and SVI $\left(Y_{4}\right)$.

147 For $n$ number of factors, the total number of experiments to be conducted for a central composite 148 design is based on $2 n$ axial points, $2^{n}$ factorial points and the number of replications. Therefore, 149 for two (2) independent variables in a $2^{2}$ full factorial central composite design, a total number of 150 thirteen (13) experiments made up of four (4) axial points, four (4) factorial points and five (5) 151 replicates at the centre points as shown in Equation (3) are required. The effect of residual error 152 was reduced by randomizing the experimental runs.

$$
N_{\text {expt }}=2^{n}+2 n+c=4+4+5=13
$$


153 where, $N_{\text {expt }}$ is the total number of experimental runs, $n$ is number of independent variables, $c$ is 154 the number of replications at the centre point.

155 The axial points are fixed at a distance, $\alpha$ from the centre with coordinates of $(0, \pm \alpha)$ and $( \pm \alpha, 0)$ 156 for two (2) independent variables in a central composite design. The value of $\alpha$ is computed from 157 the expression $\left(2^{n}\right)^{0.25}$ and this value is 1.414 for two independent variable, $n=2$.

158 Preliminary experiments were conducted to set the range for the alum concentrations and 159 wastewater $\mathrm{pH}$. It was observed that alum was effective within the dosages of 7 to $17 \mathrm{~g} / \mathrm{L}$ and a $\mathrm{pH}$ 160 range from 6 to 9 . The levels for each independent variable were given the codes $+1,0$ and -1 161 designating the high, medium and low levels of the factorial points respectively. The ranges and 162 levels of the independent factors are shown in Table 1.

163 Table 1 Range and levels of independent variables.

\begin{tabular}{lllllll}
\hline \multirow{2}{*}{ Variables } & Code & \multicolumn{2}{l}{ Range and levels } & & \\
\cline { 3 - 7 } & & $-\alpha^{\mathrm{a}}$ & -1 & 0 & +1 & $+\alpha$ \\
\hline Dosage (g/L) & $X_{1}$ & 6.34 & 8 & 12 & 16 & 17.66 \\
$\mathrm{pH}(-)$ & $X_{2}$ & 6.09 & 6.5 & 7.5 & 8.5 & 8.91 \\
\hline
\end{tabular}

166 Based on the experimental results, second-order polynomial models were developed for each of 167 the responses. A general formula for the polynomial is shown in Equation (4).

$$
Y=\beta_{O}+\sum_{i=1}^{n} \beta_{i} X_{i}+\sum_{i=1}^{n} \beta_{i i} X_{i}^{2}+\sum_{i=1}^{n} \sum_{j=1}^{n} \beta_{i j} X_{i} X_{j}+\varepsilon
$$


169 where $Y$ represents the predicted response; $\beta_{O}, \beta_{i}$ and $\beta_{i j}$ are collectively termed as the model

170 coefficients, $\beta_{O}$ is the constant coefficient, $\beta_{i}, \beta_{i i}$ and $\beta_{i j}$ are the linear, quadratic and interaction 171 coefficients respectively. $\varepsilon$ is the error associated with the model. $X_{i}$ and $X_{j}$ are the codes given 172 to the two independent variables (coagulant dosage and $\mathrm{pH}$ ). Statistical significance of the 173 regression models was evaluated by conducting Analysis of Variance (ANOVA) test. The 174 significance of the model coefficients was assessed using Fisher's F-test with the $p$-value at the 175 confidence interval of 95\%. The model adequacy was assessed using the coefficient of 176 determination $\left(\mathrm{R}^{2}\right)$ and lack-of-fit test. From the models, surface and contour plots showing the 177 interaction effect of the process parameters and the optimum regions of the coagulation process 178 were obtained for each of the responses. The optimum process parameters defined by the models 179 were verified experimentally (Hamid et al. 2014). The experimental design matrices, statistical 180 analyses and optimization processes were performed using the Minitab statistical software package 181 version 17.

\section{Results and Discussion}

\section{Artisanal tannery wastewater characteristics}

184 The physicochemical characteristics of artisanal tannery wastewater are presented in Table 2 . The 185 wastewater is slightly acidic with an average $\mathrm{pH}$ value of 6.29 which falls within the acceptable 186 range of the Ghana Environmenal Protection Agency (2016) standards. It is dark-red in appearance 187 (22400PtCo) due to the use of tannins and dyes in the production process. The electrical conductivity $(9370 \mu \mathrm{S})$ and total dissolved solids $(4585.25 \mathrm{mg} / \mathrm{L})$ exceeded the stipulated standard of $1500 \mu \mathrm{S}$ and $1000 \mathrm{mg} / \mathrm{L}$ respectively. 
191 Table 2 Characteristics of artisanal tannery wastewater.

\begin{tabular}{llll}
\hline Parameter & Unit & Average & Ghana EPA (2016) \\
\hline $\mathrm{pH}$ & - & $6.29 \pm 0.35$ & $6.0-9.0$ \\
Colour & PtCo & $22400 \pm 5931.86$ & 10 \\
$\mathrm{EC}$ & $\mu \mathrm{S}$ & $9370 \pm 0.99$ & 1500 \\
$\mathrm{TDS}$ & $\mathrm{mg} / \mathrm{L}$ & $4585.25 \pm 473.92$ & 1000 \\
$\mathrm{TSS}$ & $\mathrm{mg} / \mathrm{L}$ & $3441.25 \pm 621.63$ & 50 \\
Turbidity & $\mathrm{NTU}$ & $1380 \pm 399.53$ & 75 \\
$\mathrm{COD}$ & $\mathrm{mg} / \mathrm{L}$ & $24928 \pm 327.26$ & 250 \\
$\mathrm{BOD} 5$ & $\mathrm{mg} / \mathrm{L}$ & $2639 \pm 25.56$ & 50 \\
$\mathrm{BOD}_{5}$ COD & - & 0.11 & - \\
$\mathrm{NH}_{3}-\mathrm{N}$ & $\mathrm{mg} / \mathrm{L}$ & $10.15 \pm 3.32$ & 1 \\
$\mathrm{TN}^{-\mathrm{N}}$ & $\mathrm{mg} / \mathrm{L}$ & $36.70 \pm 5.45$ & 50 \\
$\mathrm{Cl}^{-}$ & $\mathrm{mg} / \mathrm{L}$ & $722 \pm 56$ & -
\end{tabular}

193 The wastewater is also heavily laden with suspended matter with a mean concentration of $1943441.25 \mathrm{mg} / \mathrm{L}$ which contributes to its high turbidity value of $1380 \mathrm{NTU}$. The suspended matter 195 originates from the use of crushed pods of Acacia nilotica and sorghum leaf sheaths in the leather 196 making process. The total suspended solids and turbidity also exceeded the limits $(50 \mathrm{mg} / \mathrm{L}$ and 197 75NTU respectively) set by Ghana Environmenal Protection Agency (2016). The organic 198 component of the wastewater measured as COD $(24928 \mathrm{mg} / \mathrm{L})$ and $\mathrm{BOD}_{5}(2639 \mathrm{mg} / \mathrm{L})$ was also 199 very high exceeding the limits of $250 \mathrm{mg} / \mathrm{L}$ and 50mg/L respectively by approximately 38 and 21 200 times respectively. The biodegradability index (BOD $5 / C O D)$ of the wastewater was 0.11 
201 signifying its high non-biodegradability nature (Andrio et al. 2019) due to the presence of tannins 202 and natural dyes (Schrank et al. 2004). The nitrogenous component with average values of

203

204

205

206

207

208

209

210

211

212

$$
\begin{gathered}
Y_{1}(\%)=213.6-0.83 X_{1}-47.36 X_{2}-0.1637 X_{1}^{2}+2.431 X_{2}^{2}+0.775 X_{1} X_{2} \\
\left(R^{2}=97.92 \%, R_{a d j}^{2}=96.43 \%\right) \\
Y_{2}(\%)=128.1+0.305 X_{1}-13.839 X_{2}-0.0644 X_{1}^{2}+0.78 X_{2}^{2}+0.1182 X_{1} X_{2} \\
\left(R^{2}=96.00 \%, R_{a d j}^{2}=93.15 \%\right) \\
Y_{3}(\%)=57.20+1.537 X_{1}+3.65 X_{2}-0.1021 X_{1}^{2}-0.420 X_{2}^{2}+0.161 X_{1} X_{2} \\
\left(R^{2}=91.69 \%, R_{a d j}^{2}=85.76 \%\right) \\
Y_{4}(m L / g)=174.82+0.78 X_{1}-44.17 X_{2}+0.05828 X_{1}^{2}+3.632 X_{2}^{2}-0.3942 X_{1} X_{2} \\
\left(R^{2}=98.69 \%, R_{a d j}^{2}=97.76 \%\right)
\end{gathered}
$$

214 From the regression models, the coefficients of the individual factors, namely, alum dosage $\left(X_{1}\right)$ 215 and $\mathrm{pH}\left(X_{2}\right)$ depict the linear effects of the factors on the coagulation process. Whilst the 216 coefficients of $X_{1}^{2}$ and $X_{2}^{2}$ reveal the quadratic effect of the factors and that of $X_{1} X_{2}$ shows the 
217 effect of the interaction between $X_{1}$ and $X_{2}$ on the process. The presence of a positive sign before

218 a term denotes a synergistic effect on the coagulation process whilst the occurrence of a minus

219 sign signifies an antagonistic effect (Kim 2016).

220 To ensure accuracy, the adequacy of the regression models was checked before the optimization

221 process to ensure they give a good approximation of the actual coagulation process. The adequacy

222 of the model was assessed by comparing the predicted and the actual values of the responses (Fig.

223 1). As can be observed from Fig. 1 the predicted values are in close agreement with the

224 experimental data indicating good fits.

225 The models were also validated by conducting ANOVA using the Fisher's test (F-test) to 226 determine their statistical significance. The results are given in Table 4. The statistical significance 227 of the model was judged from the $F$ and $p$-values. Generally, large $F$ values and small $p$ values 228 (<0.05) signify a significant difference at a confidence interval of $95 \%$. As can be observed from 229 the table, the $p$-values for COD, TSS, turbidity removal efficiencies and SVI were 0.00, 0.00, 0.001 230 and 0.00 respectively depicting the statistical significance of all the four models. Additionally, the 231 lack-of-fit of a regression model which indicates the differences in the experimental results around 232 the fitted quadratic model can be used to assess the validity of the model. From the F-test, the lack233 of-fit becomes statistically significant (for $p<0.05$ ) if the model is not well fitted to the data. 
Table 3 Central Composite Design matrix for coagulation experiments with alum coagulant.

\begin{tabular}{|c|c|c|c|c|c|c|c|c|c|c|c|c|c|}
\hline \multirow{3}{*}{$\begin{array}{l}\text { Std } \\
\text { order }\end{array}$} & \multirow{3}{*}{$\begin{array}{l}\text { Run } \\
\text { order }\end{array}$} & \multicolumn{4}{|c|}{ Independent Variables } & \multicolumn{8}{|c|}{ Responses } \\
\hline & & \multicolumn{2}{|c|}{$\begin{array}{l}\text { Alum dosage }\left(X_{l}\right) \\
(\mathrm{g} / \mathrm{L})\end{array}$} & \multicolumn{2}{|c|}{$\mathrm{pH}, X_{2}$} & \multicolumn{2}{|c|}{$\begin{array}{c}\text { COD removal, } \\
Y_{1}(\%)\end{array}$} & \multicolumn{2}{|c|}{$\begin{array}{c}\text { TSS Removal, } Y_{2} \\
(\%)\end{array}$} & \multicolumn{2}{|c|}{$\begin{array}{c}\text { Turbidity } \\
\text { Removal, } Y_{3}(\%)\end{array}$} & \multicolumn{2}{|c|}{$\mathrm{SVI}, Y_{4}(\mathrm{~mL} / \mathrm{g})$} \\
\hline & & Coded & Uncoded & Coded & Uncoded & $\operatorname{Expt}^{\mathrm{a}}$ & Pred $^{b}$ & $\mathrm{Expt}^{\mathrm{a}}$ & Pred $^{b}$ & $\mathrm{Expt}^{\mathrm{a}}$ & Pred $^{b}$ & $\mathrm{Expt}^{\mathrm{a}}$ & Pred $^{b}$ \\
\hline 4 & 1 & +1 & 16 & +1 & 8.5 & 36.91 & 36.93 & 71.07 & 71.37 & 78.93 & 78.56 & 35.09 & 35.54 \\
\hline 6 & 2 & $+\alpha$ & 17.66 & 0 & 7.5 & 32.30 & 32.13 & 69.52 & 69.21 & 78.06 & 77.90 & 27.97 & 27.55 \\
\hline 7 & 3 & 0 & 12 & $-\alpha$ & 6.09 & 39.22 & 38.52 & 76.03 & 75.85 & 80.46 & 79.68 & 29.26 & 29.47 \\
\hline 12 & 4 & 0 & 12 & 0 & 7.5 & 32.34 & 31.40 & 73.89 & 73.28 & 79.05 & 79.51 & 30.23 & 30.09 \\
\hline 13 & 5 & 0 & 12 & 0 & 7.5 & 30.18 & 31.40 & 72.78 & 73.28 & 80.01 & 79.51 & 29.84 & 30.09 \\
\hline 9 & 6 & 0 & 12 & 0 & 7.5 & 31.97 & 31.40 & 73.01 & 73.28 & 80.13 & 79.51 & 30.39 & 30.09 \\
\hline 10 & 7 & 0 & 12 & 0 & 7.5 & 32.22 & 31.40 & 72.94 & 73.28 & 79.32 & 79.51 & 30.03 & 30.09 \\
\hline 2 & 8 & +1 & 16 & -1 & 6.5 & 33.47 & 33.93 & 71.59 & 71.85 & 78.06 & 78.70 & 27.41 & 27.55 \\
\hline 11 & 9 & 0 & 12 & 0 & 7.5 & 30.29 & 31.40 & 73.78 & 73.28 & 79.03 & 79.51 & 29.95 & 30.09 \\
\hline 5 & 10 & $-\alpha$ & 6.34 & 0 & 7.5 & 20.81 & 20.20 & 73.32 & 73.23 & 74.54 & 74.58 & 35.95 & 36.35 \\
\hline 8 & 11 & 0 & 12 & $+\alpha$ & 8.91 & 34.10 & 34.01 & 74.05 & 73.83 & 77.00 & 77.65 & 45.46 & 45.23 \\
\hline 1 & 12 & -1 & 8 & -1 & 6.5 & 30.92 & 31.69 & 75.53 & 75.64 & 77.14 & 77.64 & 31.05 & 30.61 \\
\hline 3 & 13 & -1 & 8 & +1 & 8.5 & 21.97 & 22.30 & 73.12 & 73.26 & 75.43 & 74.92 & 45.04 & 44.91 \\
\hline
\end{tabular}


236 However, from Table 4, the large $p$-values for lack-of-fit of the four models which were 0.688 for

237 COD removal, 0.72 for TSS removal, 0.194 for turbidity removal and 0.062 for SVI reveal the

238 high precision of the models.

239 Furthermore, the precision of the model can be judged from the coefficient of determination $\left(R^{2}\right)$.

240 An $R^{2}$ value above $75 \%$ which is also close to the adjusted $R^{2}$ values is usually desired (Hamid et

241 al. 2014). The $R^{2}$ values obtained for COD, TSS and turbidity removal efficiencies as well as for

242 SVI were $97.92 \%, 96 \%, 91.69$ and $98.69 \%$ respectively. Hence, only about $2.07 \%, 4 \%, 8.31 \%$ and

$243 \quad 1.31 \%$ of the total variation in the respective models could not be explained by the regression

244 models. The values of the adjusted $R^{2}$ for all the four models were also near to the respective $R^{2}$ 245 values which also indicates that the quadratic models give a good prediction of the experimental 246 data.
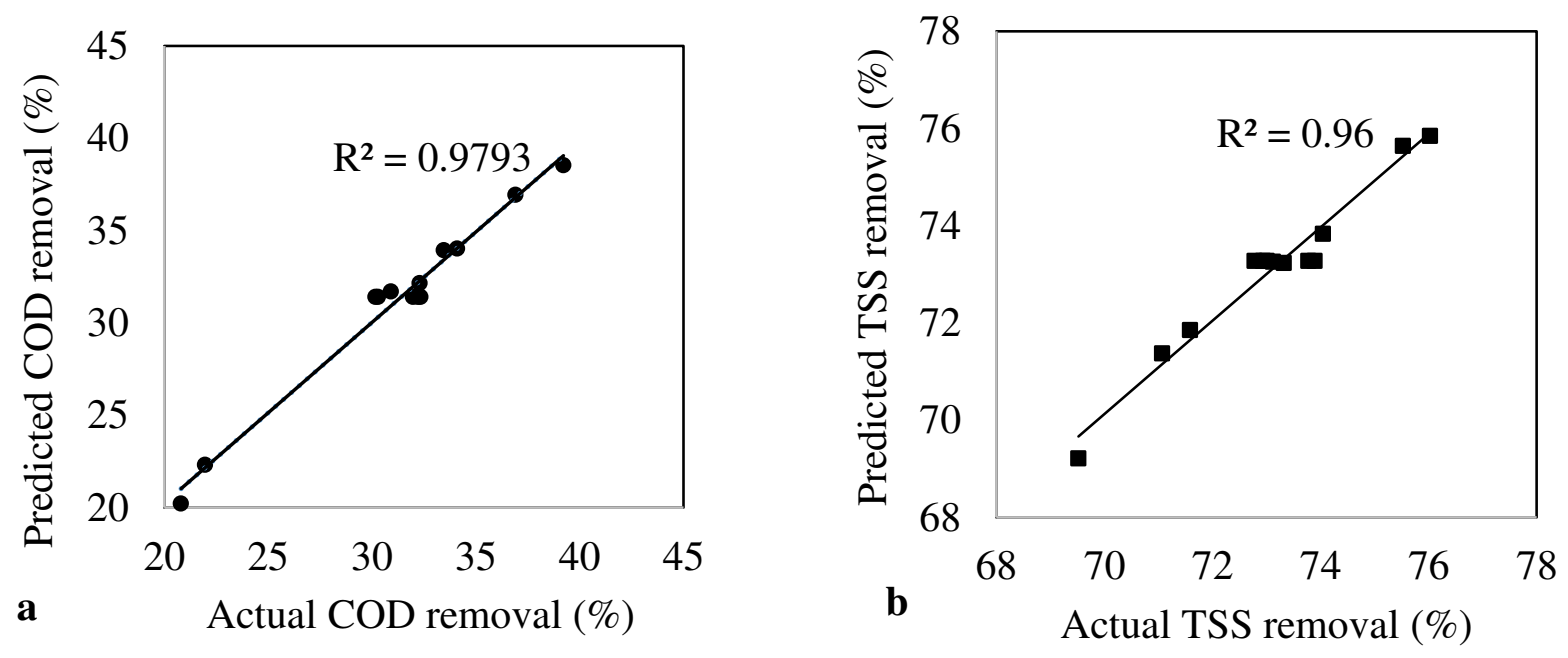

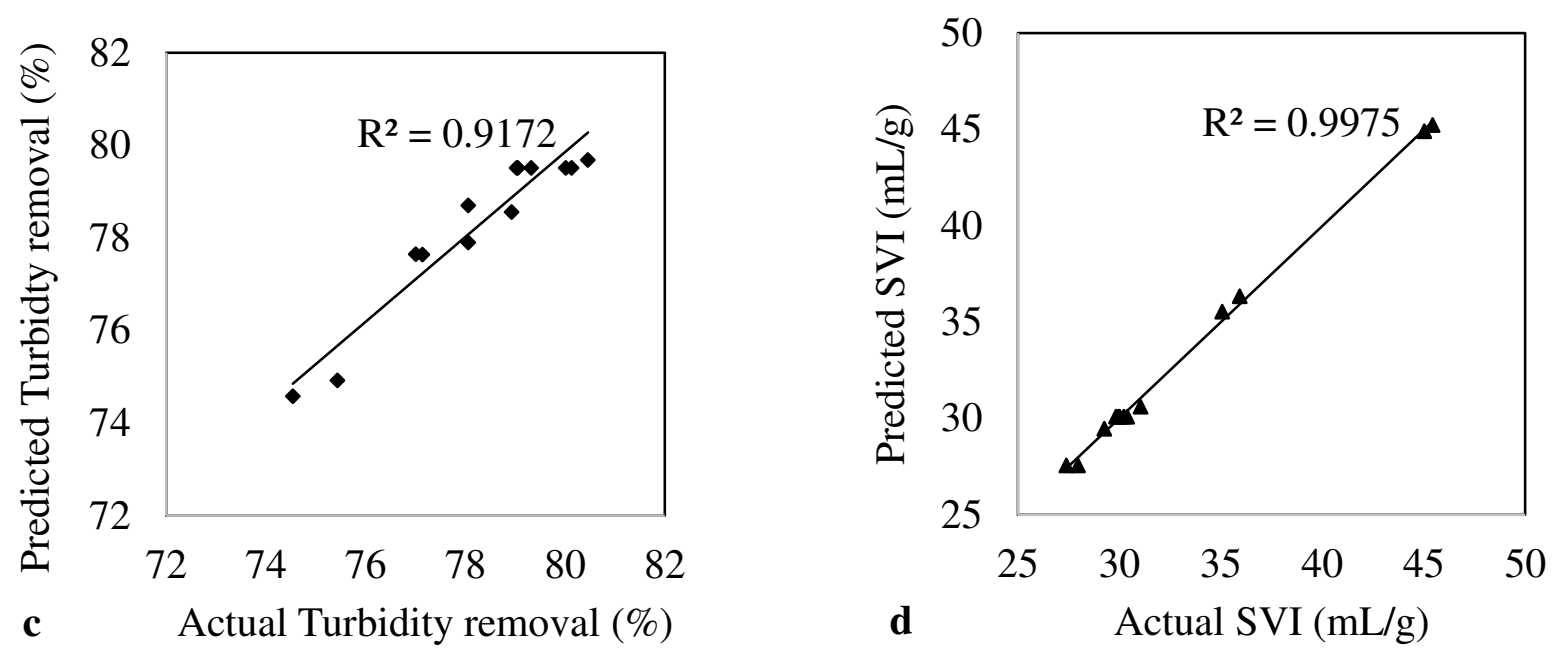

249

Fig. 1 Predicted versus actual (a) \% COD removal, $\mathrm{Y}_{1}$ (b) $\%$ TSS removal, $\mathrm{Y}_{2}$ (c) \% turbidity removal, $\mathrm{Y}_{3}(\mathrm{~d}) \mathrm{SVI}, \mathrm{Y}_{4}(\mathrm{~mL} / \mathrm{g})$ with alum as coagulant

\section{Optimization of coagulation-flocculation process}

253 Effect of process parameters on removal of COD, TSS and turbidity from artisanal tannery

254 wastewater

255 The effect of alum dosage and initial $\mathrm{pH}$ of wastewater on removal of COD, TSS and turbidity

256 from the artisanal tannery wastewater can be evaluated by observing the combined effect of both

257 parameters on the removal efficiencies as shown in the 2D contour and 3D response surface plots

258 illustrated from Fig. 2 to Fig. 5 and by assessing the statistical significance of each of the model

259 coefficients (linear, quadratic and interaction terms) using the Fisher's test and $p$-values as shown

260 in Table 4. Generally, as the $F$-value increases, the corresponding $p$-value decreases and the

261 associated model coefficient becomes increasingly significant (Hamid et al. 2014).

262 From the table, all model terms; alum dosage $\left(X_{1}\right)$, initial $\mathrm{pH}$ of the tannery wastewater $\left(X_{2}\right)$, the

263 square of both factors $\left(X_{1}^{2}\right.$ and $\left.X_{2}^{2}\right)$ as well as their interaction effect $\left(X_{1} X_{2}\right)$ had significant 


\begin{tabular}{|c|c|c|c|c|c|c|c|c|c|c|c|c|c|c|c|c|c|}
\hline \multirow[t]{2}{*}{ Source } & \multirow{2}{*}{$\begin{array}{l}\text { d. } \\
\text { f }\end{array}$} & \multicolumn{4}{|c|}{ Adj SS } & \multicolumn{4}{|c|}{ Adj. MS } & \multicolumn{4}{|c|}{$F$-value } & \multicolumn{4}{|c|}{$p$-value } \\
\hline & & $Y_{1}$ & $Y_{2}$ & $Y_{3}$ & $Y_{4}$ & $Y_{1}$ & $Y_{2}$ & $Y_{3}$ & $Y_{4}$ & $Y_{1}$ & $Y_{2}$ & $Y_{3}$ & $Y_{4}$ & $Y_{1}$ & $Y_{2}$ & $Y_{3}$ & $Y_{4}$ \\
\hline Model & 5 & 303 & 34.4 & 35.7 & 429 & 60.6 & 6.88 & 7.14 & 85.8 & 66.2 & 33.6 & 15.5 & 572 & 0.000 & 0.000 & 0.001 & 0.000 \\
\hline$X_{1}$ & 1 & 103 & 2.00 & 26.0 & 24.6 & 103 & 2.00 & 26.0 & 24.6 & 112 & 9.63 & 56.4 & 164 & 0.000 & 0.017 & 0.000 & 0.000 \\
\hline$X_{2}$ & 1 & 56.7 & 3.00 & 4.12 & 91.6 & 56.7 & 3.00 & 4.12 & 91.6 & 61.8 & 14.4 & 8.92 & 611 & 0.000 & 0.007 & 0.020 & 0.000 \\
\hline$X_{1}^{2}$ & 1 & 47.7 & 7.39 & 18.6 & 6.05 & 47.7 & 7.39 & 18.6 & 6.05 & 55.7 & 36.1 & 40.2 & 40.3 & 0.000 & 0.001 & 0.000 & 0.000 \\
\hline$X_{2}^{2}$ & 1 & 41.1 & 4.23 & 1.23 & 91.7 & 41.1 & 4.23 & 1.23 & 91.7 & 52.1 & 20.7 & 2.65 & 612 & 0.000 & 0.003 & 0.147 & 0.000 \\
\hline$X_{1} X_{2}$ & 1 & 38.4 & 0.89 & 1.66 & 9.43 & 38.4 & 0.89 & 1.66 & 9.94 & 41.9 & 4.36 & 3.59 & 66.3 & 0.000 & 0.075 & 0.100 & 0.000 \\
\hline Total error & 7 & 6.41 & 1.43 & 3.23 & 1.05 & 0.92 & 0.21 & 0.46 & 0.15 & & & & & & & & \\
\hline Lack of fit & 3 & 1.81 & 0.37 & 2.12 & 0.85 & 0.60 & 0.12 & 0.71 & 0.28 & 0.53 & 0.47 & 2.55 & 5.77 & 0.688 & 0.72 & 0.194 & 0.062 \\
\hline Pure error & 4 & 4.60 & 1.06 & 1.11 & 0.20 & 1.15 & 0.27 & 0.28 & 0.05 & & & & & & & & \\
\hline
\end{tabular}


266 influence on COD removal efficiency with each having a $p$-value of 0.00 . Observation of the 267 contour and response surface plots in Fig. 2 shows that removal efficiency of COD generally 268 decreased with increasing $\mathrm{pH}$ but increased with increasing alum concentration until a dosage of 269 16.2gAlum/L. The optimum range for a maximum COD removal efficiency above 35\% occurred 270 within two regions: a pH range of 6 to 6.5 and alum dosage range of 7.8 to $16.2 \mathrm{~g} / \mathrm{L}$ and also from $271 \mathrm{pH} 8.2$ to 9 and an alum dosage range of 16 to $18 \mathrm{~g} / \mathrm{L}$. Outside these optimal regions, COD removal 272 efficiency declined. The percentage COD removal is quite low depicting that most of the COD 273 exist in the soluble form. The removal efficiency obtained agrees with that reported by Shewa \& 274 Dagnew (2020).

275 For TSS, the square of alum dosage, $X_{1}^{2}(p=0.001)$ had the greatest influence in its removal, 276 followed by the square of $\mathrm{pH}, X_{2}^{2}(p=0.003)$, the $\mathrm{pH}$ of the wastewater, $X_{2}(p=0.007)$ and then the 277 alum dosage, $X_{1}(p=0.017)$. The interaction of the factors $\left(X_{1} X_{2}\right)$ was, however, statistically 278 insignificant in the TSS removal efficiency $(p=0.075)$ (Table 4). From the plots shown in Figure 2793 , the removal efficiency of TSS decreased with increasing $\mathrm{pH}$. It, however, increased with alum 280 dosage from 6 to $11.8 \mathrm{~g} / \mathrm{L}$ and then decreased with further increase in alum concentration. A 281 maximum TSS removal efficiency above $76 \%$ can be attained at the optimal ranges of 6 to 6.3 for $282 \mathrm{pH}$ and 6.6 to $11.8 \mathrm{~g} / \mathrm{L}$ for alum dosage.

283 With regards to turbidity, the alum dosage, $X_{1}$ and its square, $X_{1}^{2}$ were the most significant 284 parameters in the removal efficiency at $p=0.00$. The $\mathrm{pH}, X_{2}(p=0.02)$ also played a significant role 285 in the removal efficiency. However, both the square of $\mathrm{pH}, X_{2}^{2}(p=0.147)$ and the interaction of 286 both factors, $X_{1} X_{2}(p=0.1)$ were statistically insignificant in the turbidity removal from the 287 wastewater. Observing Fig. 4, there was a general decrease in the turbidity removal with increasing $288 \mathrm{pH}$ and an increase with increasing alum dosage up to $13.8 \mathrm{~g} / \mathrm{L}$. Beyond this concentration, the 

$79.5 \%$ lies between 6 and 7.7 for $\mathrm{pH}$ and 11 to $13.8 \mathrm{~g} / \mathrm{L}$ for alum dosage.
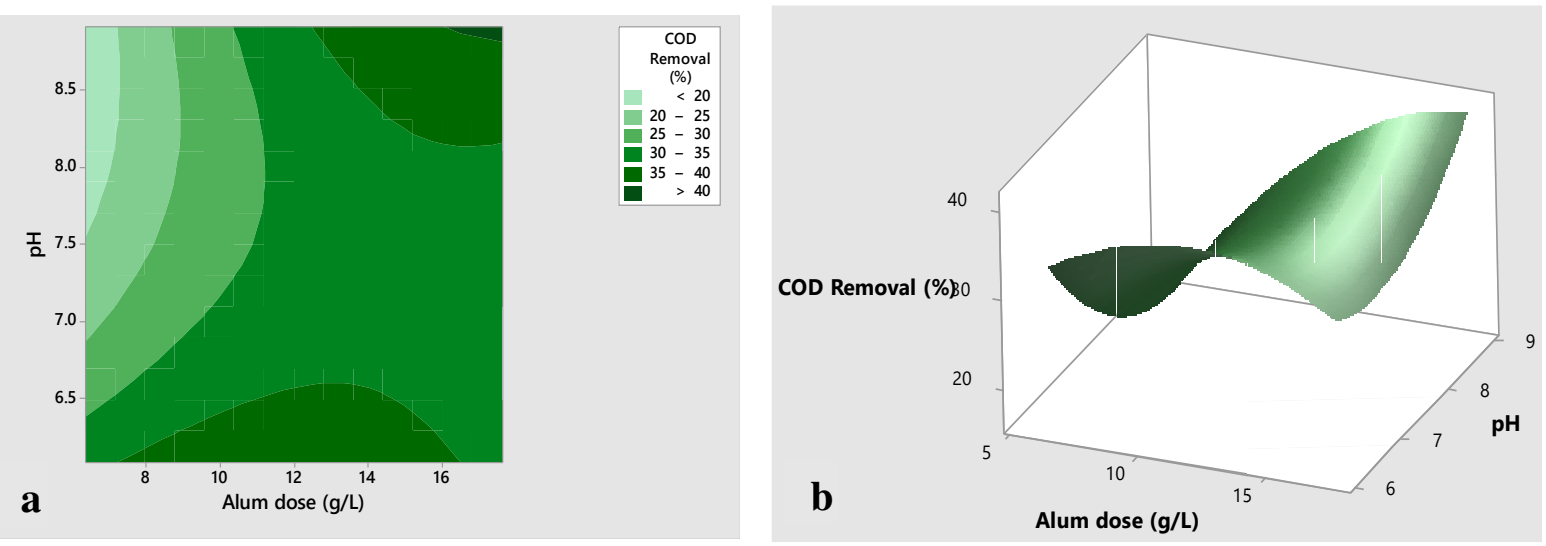

Fig. 2 (a) Contour and (b) response surface plots showing the combined effect of alum dosage and $\mathrm{pH}$ on COD removal efficiency
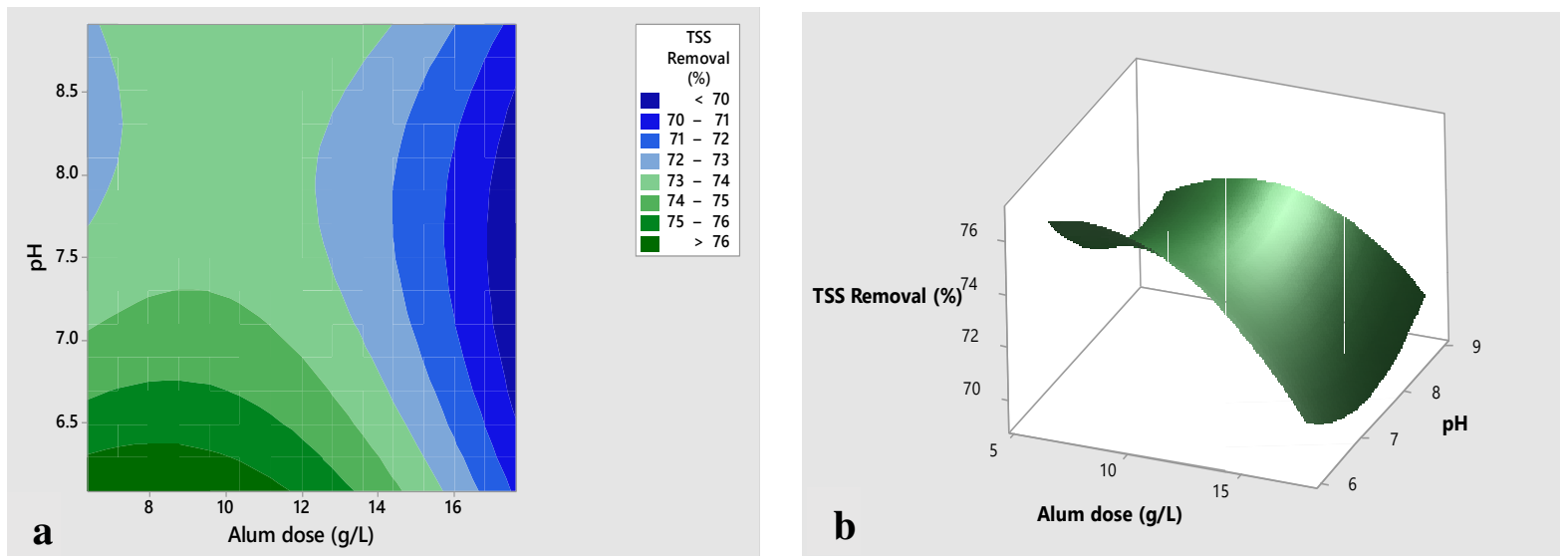

Figure 3 (a) Contour and (b) response surface plots showing the combined effect of alum dosage and $\mathrm{pH}$ on TSS removal efficiency 

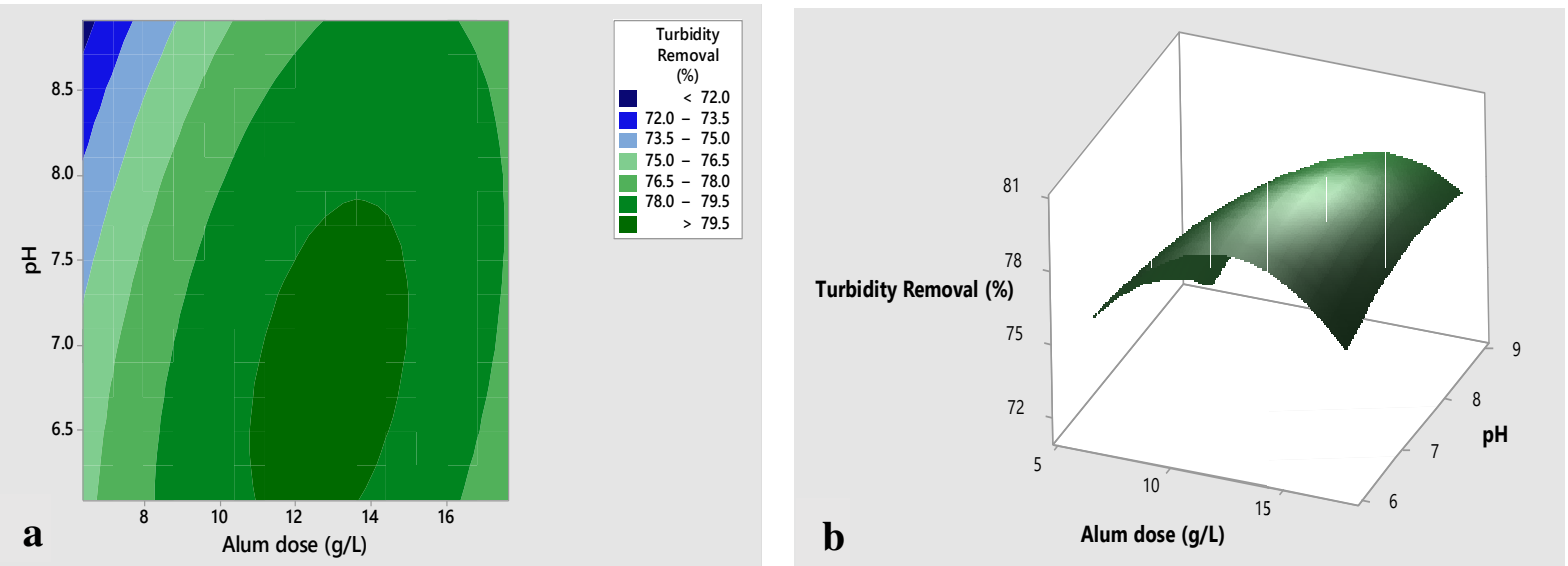

Fig. 4 (a) Contour and (b) response surface plots showing the combined effect of alum dosage and $\mathrm{pH}$ on turbidity removal efficiency
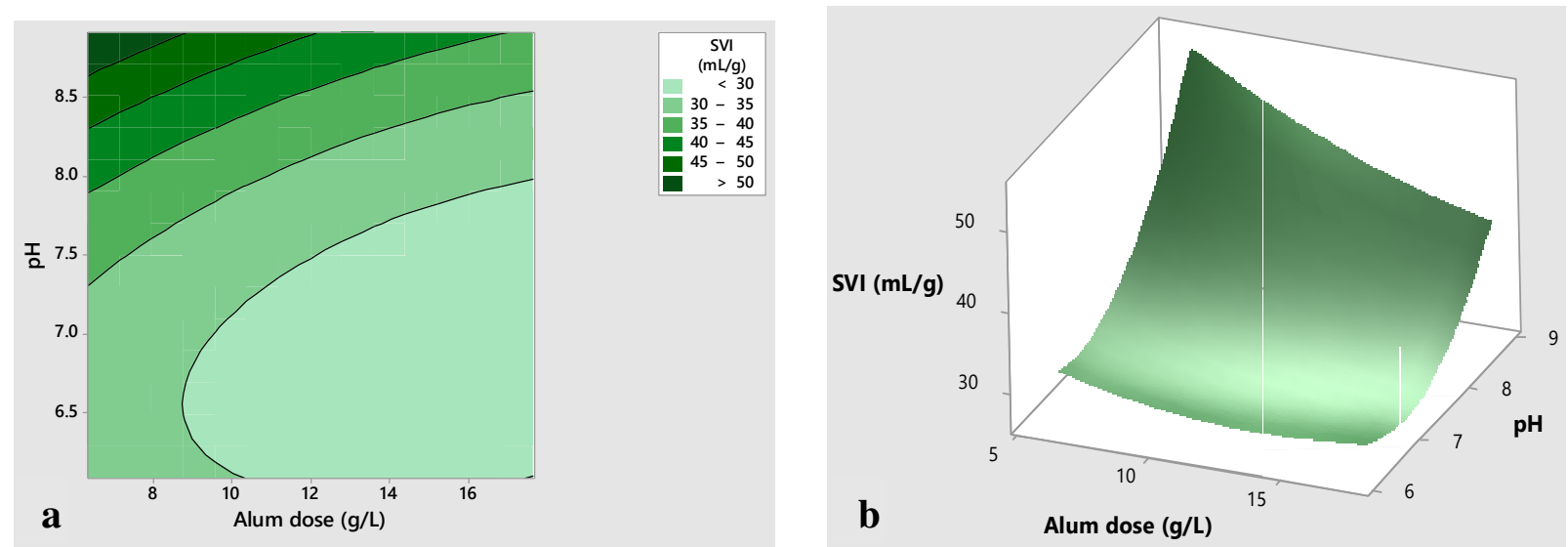

Fig. 5 (a) Contour and (b) response surface plots showing the combined effect of alum dosage and $\mathrm{pH}$ on SVI

The results indicate the essential roles of $\mathrm{pH}$ and alum dosage in the efficiency of the coagulation process. At $\mathrm{pH}$ range between 6 and 7, the addition of aluminium sulphate to the wastewater

306 releases aluminium ions $\left(\mathrm{Al}^{3+}\right)$ which undergo hydrolytic reactions with hydroxide ions $\left(\mathrm{OH}^{-}\right)$in 307 the wastewater to form hydrogen ions and different species of aluminium hydroxide compounds: 
$\mathrm{Al}^{3+}, \mathrm{Al}(\mathrm{OH})_{2}^{+}, \mathrm{Al}(\mathrm{OH})^{2+}, \mathrm{Al}(\mathrm{OH})_{3(\mathrm{~s})}$ and $\mathrm{Al}(\mathrm{OH})_{4}^{-}$(Pernitsky \& Edzwald 2006) as shown in Equation (9) to (12) (Nowacka et al. 2014). These compounds coexist in solution at different concentrations depending on the $\mathrm{pH}$. The negatively charged colloidal particles in the wastewater get adsorbed onto these positively charged aluminium hydroxide species leading to neutralisation

312 of surface charges on the colloidal particles. The repulsion energy of the colloids diminishes and 313 the colloids are destabilised through the adsorption and neutralisation mechanism. Subsequently, 314 aluminium hydroxide-colloid complexes are formed which aggregate into large floc particles 315 capable of settling easily out of solution to form sludge (Ghernaout et al. 2009).

316

$$
\begin{gathered}
\mathrm{Al}^{3+}+\mathrm{H}_{2} \mathrm{O} \leftrightarrow \mathrm{Al}(\mathrm{OH})^{2+}+\mathrm{H}^{+} \\
\mathrm{Al}(\mathrm{OH})^{2+}+\mathrm{H}_{2} \mathrm{O} \leftrightarrow \mathrm{Al}(\mathrm{OH})_{2}^{+}+\mathrm{H}^{+} \\
\mathrm{Al}(\mathrm{OH})_{2}^{+}+\mathrm{H}_{2} \mathrm{O} \leftrightarrow \mathrm{Al}(\mathrm{OH})_{3}+\mathrm{H}^{+} \\
\mathrm{Al}(\mathrm{OH})_{3}+\mathrm{H}_{2} \mathrm{O} \leftrightarrow \mathrm{Al}(\mathrm{OH})_{4}^{-}+\mathrm{H}^{+}
\end{gathered}
$$

317 Sweep flocculation is another coagulation mechanism which could have occurred simultaneously 318 with the adsorption and charge neutralisation mechanism in destabilising the colloidal particles.

319 This phenomenon occurs when the aluminium sulphate concentration is high enough and it 320 involves the entrapment of colloidal particles into the aluminium hydroxide precipitates $321\left[\mathrm{Al}(\mathrm{OH})_{3(\mathrm{~s})}\right]$. The entrapment usually happens either during the formation of the $\mathrm{Al}(\mathrm{OH})_{3}$ 322 precipitates or afterwards when some of the colloids are adsorbed onto the amorphous, large 323 surface area of the precipitates. The process results in the formation of dense, stable flocs and as 324 they fall to the bottom of the jar, they 'sweep' most of the colloidal particles alongside with them 325 (Ghernaout \& Ghernaout 2012). 
326 Thus, the major pathways by which TSS, COD and turbidity were removed from the wastewater 327 were adsorption, charge neutralisation and sweep flocculation mechanisms. According to 328 Ghernaout \& Ghernaout (2012), highly turbid wastewaters such as tannery wastewater are best 329 treated within the optimum $\mathrm{pH}$ range of 5 to 7 which agrees with the optimum $\mathrm{pH}$ range within 6 330 and 7 obtained in this study. Other authors such as Malik (2018) reported that maximum turbidty 331 removal from muddy water using alum occurred at an optimum pH of 6. Mehmood et al. (2019) 332 also observed maximum reduction in COD, TSS, turbidity and colour from pulp and paper mill 333 wastewater at an optimum $\mathrm{pH}$ of 6.

334 Beyond $\mathrm{pH} 7$, the different species of the positively charged alumiium hydroxide $\left(\mathrm{Al}^{3+}, \mathrm{Al}(\mathrm{OH})_{2}^{+}\right.$, $\left.335 \mathrm{Al}(\mathrm{OH})^{2+}\right)$ are transformed into the negatively charged aluminium tetrahydroxide $\left.\mathrm{Al}(\mathrm{OH})_{4}^{-}\right)$. The 336 concentration of aluminium hydroxide $\left[\mathrm{Al}(\mathrm{OH})_{3}\right]$ precipitates also decreases in solution by 337 dissolution resulting in the unavailability of precipitates for adsorption of the colloidal particles. 338 Hence, the extent of charge neutralisation and sweep flocculation mechanisms diminishes resulting 339 in lower removal efficiencies of COD, TSS and turbidity (Ghernaout et al. 2009). Decrease in low 340 coagulation efficiency of alum at high pH was also reported by Asharuddin et al. (2019).

341 The hydrogen ions produced during the hydrolytic reactions leads to a decline in the wastewater $342 \mathrm{pH}$ (Krupińska 2020). This drop in $\mathrm{pH}$ was observed in the coagulation experiment when the initial $343 \mathrm{pH}$ range between 6.09 and 8.91 dropped to ranges between 2.58 and 3.37 after the experiments.

344 From the response surface and contour plots, lower dosages of alum generally below $6.5 \mathrm{~g} / \mathrm{L}$ could 345 not yield maximum removal of the pollutants even at a $\mathrm{pH}$ range within 6 and 7 . This depicts that 346 the alum concentrations were too low to produce adequate concentrations of the aluminium 347 hydroxide species capable of providing enough surface for adsorption of the colloidal substances 348 in the wastewater (Gregory \& Duan 2001). Hence, the poor coagulation efficiency observed at low 
349 dosages. However, above this dosage to $13.4 \mathrm{~g} / \mathrm{L}$, optimum removal of the pollutants was achieved

350 probably because the aluminium hydroxide species produced were sufficient enough to cause

351 destabilisation of the colloids through charge neutralisation and sweep flocculation mechanisms

352 (Bratby 2006). The coagulation efficiency, however, decreased at concentrations above 13.4g/L

353 of alum due to excess dosage above the optimum which may have caused charge reversal of the

354 colloidal particles. Thus, the negatively charged colloids became positively charged resulting in

355 restabilisation of the colloidal paarticles in the wastewater (Gregory \& Duan 2001).

\section{Effect of process parameters on SVI}

357 From the results of the Fisher's test shown in Table 4, all the parameters, alum dosage $\left(X_{1}\right)$, initial

$358 \mathrm{pH}$ of the wastewater $\left(X_{2}\right)$, square of both factors $\left(X_{1}^{2}\right.$ and $\left.X_{2}^{2}\right)$ as well as their interaction effect $359\left(X_{1} X_{2}\right)$ had significant effect on the sludge volume index with each having $p$-values of 0.00 . The 360 response surface and contour plots (Fig. 5) revealed that SVI increased with increasing $\mathrm{pH}$ and 361 decreased with increasing alum dosage. The lowest sludge volume index that was attained was 362 below $30 \mathrm{~mL} / \mathrm{g}$ and it occurred within a $\mathrm{pH}$ range from 6 to 7.7 and an alum dosage range between 3639 and $18 \mathrm{~g} / \mathrm{L}$.

364 At pH ranges within 6 and 7, formation of dense, macro-flocs through charge neutralisation and 365 sweep flocculation mechanisms produced well-compacted sludge of low sludge volumes and SVI. 366 However, above $\mathrm{pH} \mathrm{7,} \mathrm{the} \mathrm{reduction} \mathrm{in} \mathrm{coagulation} \mathrm{efficiency} \mathrm{due} \mathrm{to} \mathrm{the} \mathrm{decreasing} \mathrm{levels} \mathrm{of} \mathrm{the}$ 367 aluminium hydroxide precipitates could have resulted in the formation of few flocs with low 368 densities and hence, the generation of a loosely packed sludge with a higher sludge volume. The 369 attainment of negative charges on the flocs at high $\mathrm{pH}$ leading to repulsion among flocs and the 370 subsequent production of loosely-packed sludge can also explain the high SVI occuring at high $371 \mathrm{pH}($ Jin et al. 2003). 
372 The high SVI recorded at low dosages could be attributed to the poor coagulation efficiency (weak

373 neutralisation of the colloids) due to insufficient alum dosage (Wei et al. 2018). Hence, the

374 formation of less dense, micro-sized flocs resulting in poorly compacted sludge with higher sludge

375 volume and SVI. However, with increased alum concentration, coagulation efficiency was

376 enhanced which promoted the formation of macro-sized floc particles, dense enough to produce

377 tightly packed sludge with low sludge volume and SVI. Mehmood et al. (2019) in treating pulp

378 and paper mill wastewater also reported a decrease in SVI with increasing alum dosage.

379 Optimization and verification of process parameters

380 Optimization of the coagulation-flocculation process was targeted at obtaining an optimal 381 condition at which maximization of COD, TSS and turbidity removal efficiencies and 382 minimization of SVI can occur simultaneously. The response optimizer function of Minitab 16 383 was used to optimize the coagulation process. The optimum levels for $\mathrm{pH}$ and alum dosage as 384 given by the optimizer were verified through coagulation experiments. The results are detailed out 385 in Table 5. These results are in close agreement to those given by the regression models confirming 386 the accuracy of the models developed. 
Table 5 Predicted and experimental values at optimal process conditions

394

\begin{tabular}{|c|c|c|c|c|c|c|c|c|c|}
\hline Variables & & Respo & & & & & & & \\
\hline Alum dosage & $\mathrm{pH}$ & COD & moval, & TSS R & moval, & & dity & & $Y_{4}$ \\
\hline$X_{l}(\mathrm{~g} / \mathrm{L})$ & $X_{2}(-)$ & & & & $\%)$ & Remo & $Y_{3}(\%)$ & & /g) \\
\hline & & Pred $^{\mathrm{a}}$ & $\operatorname{Expt}^{\mathrm{b}}$ & Pred $^{a}$ & $\operatorname{Expt}^{\mathrm{b}}$ & Pred $^{\mathrm{a}}$ & $\mathrm{Expt}^{\mathrm{b}}$ & Pred $^{\mathrm{a}}$ & $\mathrm{Expt}^{\mathrm{b}}$ \\
\hline 11.6 & 6.09 & 38.51 & 38.95 & 76.05 & 77.16 & 79.64 & 79.81 & 29.57 & 30.14 \\
\hline
\end{tabular}

${ }^{\mathrm{a}}$ pred $=$ predicted ${ }^{\mathrm{b}}$ Expt $=$ experimental

\section{Conclusion}

397 This is the first study conducted to optimize coagulation-flocculation treatment of artisanal tannery wastewater. Response surface methodology using the central composite design was applied to assess the effect of varying $\mathrm{pH}$ and dosage of aluminium sulphate on the treatment efficiency. It was also used to develop quadratic models and to define the optimal process conditions required to maximize removal efficiencies of COD, TSS and turbidity from the wastewater whilst

402 minimizing the SVI. The results proved that at an optimal $\mathrm{pH}$ of 6.09 and aluminium sulphate 403 dosage of $11.60 \mathrm{~g} / \mathrm{L}$ a maximum COD removal of $38.51 \%$, TSS removal of $76.05 \%$ and turbidity 404 removal of $79.64 \%$ with a minimum SVI of $29.57 \mathrm{~mL} / \mathrm{g}$ can be achieved. These results indicate 405 that coagulation-flocculation is a good pre-treatment option for artisanal tannery wastewater. 406 Further treatment to meet permissible discharge limit is required for this high-strength wastewater. 407 Experiments conducted to validate these optimum results also demonstrated that RSM is an 408 efficient optimization tool for the coagulation-flocculation treatment process. It is however, 409 recommended that further studies assessing the efficiency of natural coagulants in the treatment of 410 artisanal tannery wastewater should be conducted. 


\section{Declarations}

\section{Ethics approval}

413 Not applicable.

\section{Consent to participate}

415 Not applicable.

\section{Consent for publication}

417 Not applicable.

\section{Availability of data}

419 All data generated and analysed during this study are included in this published article.

420 Competing interests

421 The authors declare that they have no competing interests.

\section{$422 \quad$ Funding}

423 This study was funded by the Regional Water and Environmental Sanitation Centre Kumasi 424 (RWESCK) at the Kwame Nkrumah University of Science and Technology, Kumasi with funding 425 from Ghana Government through the World Bank under the Africa Centre's of Excellence project. 426 The views expressed in this paper do not reflect those of the World Bank, Ghana Government or 427 KNUST.

428 Author contributions 
429 Miriam Appiah-Brempong, Francis Momade, Helen Essandoh, Nana Asiedu: Conceptualization, 430 Visualization. Miriam Appiah-Brempong: Writing-original draft, Methodology, Formal analysis,

431 Data Curation. Miriam Appiah-Brempong, Samuel Dadzie: Investigation, Validation. Helen 432 Essandoh, Francis Momade, Nana Asiedu: Supervision, Writing- Review \& Editing.

\section{References}

434 Aboulhassan, MA, Souabi, S, Yaacoubi, A \& Baudu, M (2006) Improvement of paint effluents 435 coagulation using natural and synthetic coagulant aids. J Hazard Mater, 138:40-45. https//doi.org/10.1016/j.jhazmat.2006.05.040

437 Andrio, D, Asmura, J, Yenie, E \& Putri, K (2019) Enhancing BOD5/COD ratio co-substrate tofu https://doi.org/10.1051/matecconf/201927606027

APHA, AWWA \& WEF (1999) Standard methods for the examination of water and wastewater. 20th ed. Washington, D.C.

Appiah-Brempong, M, Essandoh, HMK, Asiedu, NY, Dadzie, SK \& Momade, FWY (2020) An

Asharuddin, MS, Othman, N, Zin, NSM, Tajarudin, HA \& Din, MFM (2019) Flocculation and 446 antibacterial performance of dual coagulant system of modified cassava peel starch and alum.

Bas, D \& Ismail, B H (2007) Modeling and optimization I : Usability of response surface methodology. J Food Eng, 78:836-845. https://doi.org/10.1016/j.jfoodeng.2005.11.024 
452 Covington, AD (1997) Modern tanning chemistry. Chem Soc Rev, 111-126.

453 https://doi.org/10.1039/CS9972600111

454 Dargo, H \& Ayalew, A (2014) Tannery wastewater treatment: A review. Int J Emerg Trends Sci 455 Tech, 1 (9):1488-1494

456 Durmaz, U \& Çiner, F (2017) Treatability of tannery wastewater by electrocoagulation process. Period Eng Nat Sci, 5 (2):245-250. http://dx.doi.org/10.21533/pen.v5i2.141

458

459

460

461

462

463

464

465

466

467

468

469

470

Gebremichael, B (2016) Traditional leather processing, production and marketing in amhara regional state of Ethiopia. OALib Journal, 03 (12):1-17. http://doi.org/10.4236/oalib.1102751

Ghana Environmenal Protection Agency (2016) General Environmental quality standards (Ghana). Kumasi, Ashanti Region, Ghana: n.d.

Ghernaout, D \& Ghernaout, B (2012) Sweep flocculation as a second form of charge neutralisation- A review. Desalin Water Treat, 44:15-28. https://doi.org/10.1080/19443994.2012.691699

Ghernaout, D, Ghernaout, B, Saiba, A, Boucherit, A \& Kellil, A (2009) Removal of humic acids by continuous electromagnetic treatment followed by electrocoagulation in batch using aluminium $\quad$ electrodes. 239:295-308. https://doi.org/10.1016/j.desal.2008.04.001

Gregory, J \& Duan, J (2001) Hydrolyzing metal salts as coagulants. Pure Appl Chem, 73 (12):2017-2026. http://dx.doi.org/10.1351/pac200173122017 
471 Hamid, ABS, Chowdhury, ZZ \& Karim, ZM (2014) Catalytic extraction of microcrystalline

472

473

474

475

476

477

478

479

480

481

482

483

484

485

486

487

488

489

490

491 cellulose (MCC) from Elaeis guineensis using central composite design. BioRes, 9 (4):74037426

Islam, BI, Musa, AE, Ibrahim, EH., Sharafa, SAA \& Elfaki, BM (2014) Evaluation and characterization of tannery wastewater. J For Prod Ind, 3 (3):141-150

Jaishankar, M, Tseten, T, Anbalagan, N, Mathew, BB \& Beeregowda, KN (2014) Toxicity, mechanism and health effects of some heavy metals. Interdiscip Toxicol, 7 (2): 60-72. https://doi.org/10.2478/intox-2014-0009

Jin, B, Wilén, B M. \& Lant, P (2003) A comprehensive insight into floc characteristics and their impact on compressibility and settleability of activated sludge. Chem Eng J, 95 (1-3):221234. https://doi.org/10.1016/S1385-8947(03)00108-6

Kim, S (2016) Application of response surface method as an experimental design to optimize coagulation - flocculation process for pre-treating paper wastewater. J Ind Eng Chem, 38:93102. https://doi.org/10.1016/j.jiec.2016.04.010

Krupińska, I (2020) Aluminium drinking water treatment residuals and their toxic impact on human health. Molecules, 25 (641):1-13. https://doi.org/10.3390/molecules25030641

Kumar, S, Meena, H, Chakraborty, S \& Meikap, BC (2018) Application of response surface methodology (RSM) for optimization of leaching parameters for ash reduction from low-grade coal. Int J Min Sci Technol, 28:621-629. https://doi.org/10.1016/j.ijmst.2018.04.014

Maćczak, P., Kaczmarek, H. \& Ziegler-Borowska, M. (2020) Recent achievements in polymer bio-based flocculants for water treatment. Materials, 13 (3951):1-41. 
493

494

495

496

497

498

499

500

501

502

503

504

505

506

507

508

509

510

511

512

Malik, QH (2018) Performance of alum and assorted coagulants in turbidity removal of muddy water. Appl Water Sci, 8 (40):1-4. https//doi.org/10.1007/s13201-018-0662-5

Mehmood, K, Rehman, UKS, Wang, J, Farooq, F, Mahmood, Q, Jadoon, A M, Javed, MF \& Ahmad, I. (2019) Treatment of pulp and paper industrial effluent using physicochemical process for recycling. Water, 11:1-15. https//doi.org/10.3390/w11112393

Nowacka, A, Włodarczyk-Makuła, M \& Macherzyński, B (2014) Comparison of effectiveness of coagulation with aluminum sulfate and pre-hydrolyzed aluminum coagulants. Desalin Water Treat, 52 (19-21):3843-3851. https://doi.org/10.1080/19443994.2014.888129

Paltahe, A, Cornelius, T, Sambo, B, Christian, D, Teri, T, Rallet, D. \& Wahabou, A (2019) Physico-chemical characterization of local tannery waste water before and after flocculation treatment. Int J Chem, 11 (2):77-85. https://doi.org/10.5539/ijc.v11n2p77

Pernitsky, DJ \& Edzwald, JK (2006) Selection of alum and polyaluminum coagulants: principles and applications. J Water Supply: Res Technol - AQUA, 55 (2):121-141. https://doi.org/10.2166/aqua.2006.062

Schrank, SG, José, HJ, Moreira, RFM. \& Schröder, HF (2004) Comparison of different advanced oxidation process to reduce toxicity and mineralisation of tannery wastewater. Water Sci Technol, 50 (5):329-334. https://doi.org/10.2166/wst.2004.0345

Shewa, WA \& Dagnew, M (2020) Revisiting chemically enhanced primary treatment of wastewater: A review. Sustainability, 12 (15):1-19. https://doi.org/10.3390/su12155928

Skinner, L (2007) A visit to a traditional leather tannery in central sudan. Sudan \& Nubia, 11:125- 
514 Thanikaivelan, P, Rao, JR, Nair, U B \& Ramasami, T. (2005) Technology recent trends in leather 515 making: processes , problems, and pathways recent trends in leather making: processes, 516 problems, and pathways. Critical Reviews in Environmental Science and Technology, 35 517 (1):37-79. https://doi.org/10.1080/10643380590521436

518 Verma, A K, Dash, RR \& Bhunia, P (2012) A review on chemical coagulation/flocculation 519 technologies for removal of colour from textile wastewaters. J Env Man, 93 (1): 154-168. 520 https://doi.org/10.1016/j.jenvman.2011.09.012

521 Wang, Y, Chen, K, Mo, L, Li, J \& Xu, J (2014) Optimization of coagulation - flocculation process 522 for papermaking-reconstituted tobacco slice wastewater treatment using response surface 523 methodology. J Ind Eng Chem, 20:391-396. https://doi.org/10.1016/j.jiec.2013.04.033

524 Wei, H, Gao, B, Ren, J, Li, A \& Yang, H (2018) Coagulation/flocculation in dewatering of sludge: 525 A review. Water Res, 143 (2015):608-631. https//doi.org/10.1016/j.watres.2018.07.029

526 Wemegah, R (2014) Vegetable tanning in bolgatanga: challenges and the way forward. Journal of $527 \quad$ Arts and Design Studies, 16:27-37.

528 Zaruwa, MZ \& Kwaghe, ZE (2014) Traditional tannery and dyeing (yirie) methods. In: 529 Emeagwali, G. \& Dei, G. J. S. ed., African Indigenous Knowledge and the Disciplines. Anti530 Colonial Educational Perspectives for Transformative Change. SensePublishers, Rotadam, 29- 
532 Zhao, C \& Chen, W (2019) A review for tannery wastewater treatment: some thoughts under 533 stricter discharge requirements. Environ Sci Pollut Res, 26:26102-26111. $534 \quad$ https//doi.org/10.1007/s11356-019-05699-6

535

536 